\title{
Computational Design of Metal Ion Sequestering Agents
}

EMSP Project No. 73759

\section{Annual Report June 15, 2005}

\section{Principal Investigator}

Dr. Benjamin P. Hay

Pacific Northwest National Laboratory

P.O. Box 999

Richland, WA 99352

(509) 372-6239 (phone)

(509) 375-6631 (fax)

ben.hay@pnl.gov

\section{External Collaborators}

Professor Robert T. Paine

Department of Chemistry

University of New Mexico

Albuquerque, NM 87131

(505) 277-1661 (phone)

(505) 277-2609 (fax)

rtpaine@unm.edu

Dr. Bruce A. Moyer

Chemical Sciences Division

Oak Ridge National Laboratory

Oak Ridge, TN 37831

(423) 574-6718 (phone)

(423) 574-4939 (fax)

moyerba@ornl.gov

Prof. David A. Dixon

Department of Chemistry

The University of Alabama

Tuscaloosa, AL 35487

(205) 348-8441 (phone)

(205) 348-9104 (fax)

dadixon@bama.ua.edu

\section{Co-Principal Investigator}

Dr. Brian M. Rapko

Pacific Northwest National Laboratory

P.O. Box 999

Richland, WA 99352

(509) 376-1571 (phone)

(509) 372-3861 (fax)

brian.rapko@pnl.gov

Professor Kenneth N. Raymond

Department of Chemistry

University of California, Berkeley

Berkeley, CA 94720

(510) 642-7219 (phone)

(510) 486-5283 (fax)

raymond@garnet.berkeley.edu

Prof. James E. Hutchison

Department of Chemistry

University of Oregon

Eugene, OR 97403

(541) 346-4228 (phone)

(541) 346-0487 (fax)

hutch@oregon.uoregon.edu

Prof. Jeffrey C. Bryan

Department of Chemistry

University of Wisconsin - La Crosse

La Crosse, WI 54601

(608) 785-8271 (phone)

(608) 785-8218 (fax)

bryan.jeff@uwlax.edu 


\section{Research Objective}

Organic ligands that exhibit a high degree of metal ion recognition are essential precursors for developing separation processes and sensors for metal ions. Since the beginning of the nuclear era, much research has focused on discovering ligands that target specific radionuclides. Members of the Group 1A and 2A cations (e.g., Cs, Sr, Ra) and the f-block metals (actinides and lanthanides) are of primary concern to DOE. Although there has been some success in identifying ligand architectures that exhibit a degree of metal ion recognition, the ability to control binding affinity and selectivity remains a significant challenge. The traditional approach for discovering such ligands has involved lengthy programs of organic synthesis and testing that, in the absence of reliable methods for screening compounds before synthesis, have resulted in much wasted research effort.

This project seeks to enhance and strengthen the traditional approach through computer-aided design of new and improved host molecules. Accurate electronic structure calculations are coupled with experimental data to provide fundamental information about ligand structure and the nature of metal-donor group interactions (design criteria). This fundamental information then is used in a molecular mechanics model (MM) that helps us rapidly screen proposed ligand architectures and select the best members from a set of potential candidates. By using combinatorial methods, molecule building software has been developed that generates large numbers of candidate architectures for a given set of donor groups. The specific goals of this project are:

- further understand the structural and energetic aspects of individual donor group- metal ion interactions and incorporate this information within the MM framework

- further develop and evaluate approaches for correlating ligand structure with reactivity toward metal ions, in other words, screening capability

- use molecule structure building software to generate large numbers of candidate ligand architectures for given sets of donor groups

- screen candidates and identify ligand architectures that will exhibit enhanced metal ion recognition.

These new capabilities are being applied to ligand systems identified under other DOEsponsored projects where studies have suggested that modifying existing architectures will lead to dramatic enhancements in metal ion binding affinity and selectivity. With this in mind, we are collaborating with Professors R. T. Paine (University of New Mexico), K. N. Raymond (University of California, Berkeley), and J. E. Hutchison (University of Oregon), and Dr. B. A. Moyer (Oak Ridge National Laboratory) to obtain experimental validation of the predicted new ligand structures. Successful completion of this study will yield molecular-level insight into the role that ligand architecture plays in controlling metal ion complexation and will provide a computational approach to ligand design. 


\section{Research Progress and Implications}

This project is a renewal of EMSP Project No. 73759 "Architectural Design Criteria for fBlock Metal Sequestering Agents" that began in September 2000 and ended in September 2003. This report summarizes progress after the first 18 months of the current 3-year period. Research focuses on two major areas. These are (1) expanding the functionality of our de novo structurebased design program, HostDesigner, and (2) application of computational methods to ligand design.

To bring the powerful concepts embodied in de novo structure-based drug design to the field of coordination chemistry, we have developed a computer program named HostDesigner with support from PNNL LDRD and Chemical Sciences, Office of Basic Energy Sciences, Office of Science, US DOE. This software builds millions of potential host structures from molecular fragments, screens the candidate structures with respect to their complementarity for a targeted metal ion guest, and outputs a list of lead candidates for further evaluation. One of the goals of this EMSP project is to couple the HostDesigner software with subsequent MM analyses to provide a more accurate prioritization of the candidates.

In collaboration with Dr. Kevin E. Gilbert (Serena Software), we now have completed the full automation of the MM analyses. To accomplish this, we developed an interface to a commercially available MM post-processing software module (GMMX, www.serenasoft.com) that provides access to five force field models including MMX, MM3, AMBER, MMFF94, and OPLSAA. The MM analyses occur in two steps. In the first step, a set of up to 10,000 top hits from HostDesigner are evaluated with respect to calculated guest binding energies. In the second step, a smaller subset of the top hits are conformationally searched and the candidates are sorted to give a final ranking on the basis of total reorganization energy.

To test and validate the performance of the new software, we have focused on the computeraided design of improved building blocks for crown ethers. This system was chosen because the geometric aspects of metal-ether interactions are well understood and an extended MM3 model for such complexes has been extensively validated. A series of design calculations has been completed, successfully identifying a number of candidate architectures that are much better organized for cation chelation than the archetype dimethoxyethane. The results were presented this spring at the $229^{\text {th }}$ National American Chemical Society and a manuscript describing this work is now in progress. Synthesis of several new macrocyclic ligands that incorporate the improved building blocks identified in this study is being attempted at ORNL.

HostDesigner experiences two limitations that are common to all fragment-based molecule building approaches: (1) synthesis of some candidate structures may be difficult or impossible and (2) the number of structures that can be generated is limited by the contents of the linking fragment database. We have addressed the first issue by adding descriptors to the fragment database that allow the user to exclude links with synthetically undesireable properties, for example, those that would lead to linkage isomers or give rise to chiral molecules. We are planning to address the second issue over the next year. 
A second goal of this EMSP project is apply and test the computer-aided design methodologies being developed under this project through continuing collaborations with experimental research groups. With the completion of the ether study, future efforts will be focused solely on donor groups for actinides. Because force field parameters for metal complexes are limited, an important subtask is to extend and validate parameter sets to treat donor groupactinide interactions. We are working toward extending MM models to treat the interaction of $\mathrm{f}$ block metal ions with hydroxypyridinonates, catecholates, phosphine oxides, and pyridine Noxides.

In recent interactions with the Raymond group, we have (1) further validated the ability of our extended MM models to predict the structure of catecholate and hydroxypyridinonate complexes with trivalent and tetravalent f-block metals, (2) benchmarked the accuracy of the density functional theory model (B3LYP/DZVP2) by showing that it correctly predicts barrier heights for stereochemical inversion in tris-catecholate complexes, (3) applied HostDesigner to design supramolecular assemblies composed of actinide complexes, and (4) initiated the design of actinide receptors formed by connecting multiple catecholate groups.

In recent interactions with the Paine group and Prof. Jeff Bryan (University of Wisconsin LaCrosse), we have (1) conducted a detailed analysis of the Cambridge Crystallographic Database to establish geometric parameters for the interactions between metal ions and neutral oxygen donor groups, phosphine oxide and pyridine N-oxide, (2) used our MM model to help rationalize observed reactivity in several lanthanide NOPOPO complexes, and (3) initiated the application of HostDesigner to identify optimal ligand architectures containing these neutral oxygen donor groups.

\section{Planned Activities}

- Expand HD fragment library.

- Continue the application of computer-aided design methods to identify improved host architectures for actinides.

- On-site visits with all experimental collaborators. Visits to UC-Berkeley (January 2004), the University of Oregon (November 2004), and ORNL (April 2005) have taken place. A visit to the University of New Mexico is planned for next year.

\section{Information Access}

To date, project 73759 has resulted in 18 publications and 37 presentations at meetings, workshops, and conferences (see below). In addition, two manuscripts are submitted for publication and four abstracts are submitted to future conferences. 


\section{Recent publications (2002 to date):}

- "Deliberate Design of Ligand Architecture Yields Dramatic Enhancement of Metal Ion Affinity," GJ Lumetta, BM Rapko, PA Garza, BP Hay, RD Gilbertson, TJR Weakley, and JE Hutchison, Journal of the American Chemical Society 124, 5644-5645 (2002). Highlighted as an Editors' Choice article "Designer Bindings" in Science Magazine 296, 985 (2002), as a Science Concentrate "Designed Ligands Boost Metal Binding" in Chemical and Engineering News 80(20), 37 (2002), and as a Feature Article "Designer Molecules Set the Trend for Advancing Science" on the US DOE Office of Science Website, July 29 (2002).

- "Corynebactin and a Serine Trilactone Based Analogue - Chirality and Molecular Modeling of Ferric Complexes,"M Bluhm, BP Hay, SK Sanggoo, EA Dertz, and KN Raymond, Inorganic Chemistry 41, 5475-5478 (2002).

- "A Novel Bicyclic Diamide with High Binding Affinity for Trivalent f-Block Elements," GJ Lumetta, BM Rapko, BP Hay, PA Garza, JE Hutchison, and RD Gilbertson, Solvent Extraction and Ion Exchange 21, 29-39 (2003).

- "Design, Synthesis, and Structure of Novel Cesium Receptors," JC Bryan, RA Sachleben, CT Eagle, BP Hay, C Zhang, and PV Bonnesen, Journal of Chemical Crystallography 33, 349-355 (2003).

- "Rational Design of Cesium-Selective Ionophores and Chemosensors: Dihydrocalix[4]arene Crown-6 Ethers," RA Sachleben, JC Bryan, GM Brown, R Dabestani, NL Engle, TJ Haverlock, BP Hay, HF Ji, A Urvoas, and BA Moyer, European Journal of Organic Chemistry 4862-4869 (2003).

- "Bicyclic and Acyclic Diamides. Comparison of Aqueous Phase Binding Constants with Tetra- and Hexavalent Actinides," SI Sinkov, Actinide Research Quarterly, $3^{\text {rd }} / 4^{\text {th }}$ quarter, 19-21 (2003).

- "Eight-coordinate Stereochemistries of U(IV) Catecholate and Aquo Complexes," BP Hay, J Uddin, and TK Firman, Polyhedron 23, 145-154 (2004).

- "Toward the Computer-Aided Design of Metal Ion Sequestering Agents," BP Hay, TK Firman, GJ Lumetta, BM Rapko, PA Garza, SI Sinkov, JE Hutchison, BW Parks, RD Gilbertson and TJR Weakley, Journal of Alloys and Compounds 374, 416-419 (2004).

- "Bicyclic and Acyclic Diamides: Comparison of Their Aqueous Phase Binding Constants with Am(III), Pu(IV), Np(V) and U(VI)," SI Sinkov, BM Rapko, GJ Lumetta, BP Hay, JE Hutchison and BW Parks, Inorganic Chemistry 43, 8404-8413 (2004).

- "Estimating the Number of Bound Waters in Gd(III) Complexes Revisited. Improved Methods for the Prediction of q-Values," BP Hay, EJ Werner, and KN Raymond, Bioconjugate Chemistry 15, 1496-1502 (2004).

- "The Synthesis and Lanthanide Coordination Chemistry of 2,6-Bis[(dicyclohexyl)phosphinomethyl] Pyridine N,P,P'-trioxide. The Crystal Structure of 2,6-Bis[(dicyclohexyl)phosphinomethyl] Pyridine N,P,P'-trioxide Erbium(III) Nitrate," X Gan, BM Rapko, EN Duesler, I Binyamin, RT Paine, and BP Hay, Polyhedron 24, 469-474 (2005).

- "Toward Next Generation MRI Contrast Agents: A Gadolinium Complex Bearing Three Bound Waters and an Unusually High Relaxivity," EJ Werner, MK Thompson, BP Hay, M Botta, S Aime, and KN Raymond (submitted to the Journal of the American Chemical Society).

- "Ligand Preorganization in Trivalent Lanthanide Binding by Bicyclic Malonamides Probed by Single-Phase Binding Affinity Measurements and X-Ray Crystallography," BW Parks, RD Gilbertson, JE Hutchison, E Rather, TJR Weakley, BM Rapko, BP Hay, SI Sinkov, and RD Rogers (submitted to Inorganic Chemistry).

\section{Publications from 2000 - 2002:}

- "How Strong is the C(alpha)-H $\bullet \bullet \mathrm{O}=\mathrm{C}$ Hydrogen Bond?" R Vargas, J Garza, DA Dixon, and BP Hay, Journal of the American Chemical Society 122, 4750-4755 (2000) and highlighted in Chemical and Engineering News 78(19) 15 (2000), News of the Week article "Protein Folding. Weak Hydrogen Bonds in Peptide Backbones May Play Significant Role". 


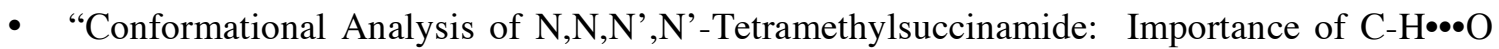
Hydrogen Bonds?" R Vargas, J Garza, DA Dixon, and BP Hay, Journal of Physical Chemistry, A, 104, 5115-5121 (2000).

- "Coordination of Lanthanide Ions Containing Non-Coordinating Counteranions with N,N,N',N'-Tetramethylsuccinamide (TMSA). I. Preparation and Characterization of [(TMSA)4Ln] $[\mathrm{A}]_{3}, \mathrm{~A}=\mathrm{ClO}_{4}{ }^{-}, \mathrm{CF}_{3} \mathrm{SO}_{3}{ }^{-}, " \mathrm{BM}$ Rapko, BK McNamara, GJ Lumetta, RD Rogers, GA Broker, and BP Hay. Inorganic Chemistry 39, 4858-4867 (2000).

- "Synthesis and Characterization of Mono- and Bis-(tetraalkyl-malonamide)uranium(VI) Complexes," GJ Lumetta, BK McNamara, BM Rapko, RL Sell, RD Rogers, GA Broker, and JE Hutchison, Inorganica Chimica Acta 309, 103-108 (2000).

- "Calorimetric and Spectroscopic Studies of Eu(III) Complexation with Tetramethylmalonamide and Tetramethylsuccinamide in Acetonitrile and Dimethylsulfoxide," L Rao, P Zanonato, P Di Bernardo, and A Bismondo, Inorganica Chimica Acta 306, 49-64 (2000).

- "Complexation of Eu(III) with Alkyl-Substituted Malonamides in Acetonitrile," L Rao, P Zanonato, P Di Bernardo, and A Bismondo. Journal of the Chemical Society, Dalton Transactions 1939-1944 (2001)

- "The Role of Donor Group Orientation as a Factor in Metal Ion Recognition by Ligands," BP Hay and RD Hancock, Coordination Chemistry Reviews 212, 61-78 (2001).

\section{Recent Presentations (2002 to date):}

- BP Hay. "Computer-Aided Design of Ion Receptors." Chemical and Analytical Division Seminar, Oak Ridge National Laboratory, Oak Ridge, Tennessee, May 2002.

- BM Rapko, GJ Lumetta, BP Hay, PA Garza, JE Hutchison, RD Gilbertson, and TR Weakley. "Bicyclic Diamides Exhibit Exceptional Affinity for Europium(III)." Actinides Separation Conference, Berkeley, California, June 2002.

- BP Hay. "Extending the MM3 Force Field for Application to the Structure-Based Design of Metal Ion Hosts." Symposium on New Developments in Force Fields for Molecular Modeling, Computers in Chemistry Division, 224 ${ }^{\text {th }}$ American Chemical Society National Meeting, Boston, Mass., August 2002.

- BP Hay, GJ Lumetta, BM Rapko, PA Garza, RD Gilbertson, TRJ Weakley, and JE Hutchison. "Deliberate Design of Ligand Architecture Yields Dramatic Enhancement in Metal Ion Affinity." Inorganic Poster Session, 224 ${ }^{\text {th }}$ American Chemical Society National Meeting, Boston, Mass., August 2002.

- C Zhang and BP Hay. "Computer-Aided Design of Cesium Receptors Based on Calix[4]arene Scaffolds." Inorganic Poster Session, 224 ${ }^{\text {th }}$ American Chemical Society National Meeting, Boston, Mass., August 2002.

- J Uddin, TK Firman, and BP Hay. "Computer Aided Design of Complementary Chelate Ring Architecture." Coordination Chemistry Symposium, Inorganic Chemistry Division, 224 American Chemical Society National Meeting, Boston, Mass., August 2002.

- RD Gilbertson, JE Hutchison, TJR Weakley, BM Rapko, and BP Hay. "Efficient Synthesis and Coordination Complexes of a New Ligand Architecture with High Affinity for f-Block Elements." Inorganic Poster Session, 224 ${ }^{\text {th }}$ American Chemical Society National Meeting, Boston, Mass., August 2002.

- BP Hay. "Toward the Computer-Aided Design of Host Molecules." Seaborg Institute Seminar Series, Los Alamos National Laboratory, Los Alamos, New Mexico, October 2002.

- BP Hay. "Toward the Computer-Aided Design of Host Molecules." Department of Chemistry, University of New Mexico, Albuquerque, New Mexico, October 2002.

- BP Hay. "Computer-Aided Host Design." Molecular Interactions and Transformations Seminar, Pacific Northwest National Laboratory, Richland, Washington, December 2002.

- JE Hutchison, RD Gilbertson, BW Parks, BP Hay, and BM Rapko, "Preorganized Malonamide Ligands: New Ligands and Materials for f-Block Ion Binding." Division of Nuclear Chemistry and Technology, $225^{\text {th }}$ American Chemical Society National Meeting, New Orleans, Louisiana, March 2003. 
- J Uddin and BP Hay. "The Computer-Aided Design of Receptors for Tetravalent Actinides." Division of Computers in Chemistry, $225^{\text {th }}$ American Chemical Society National Meeting in New Orleans, Louisiana, March 2003.

- BP Hay. "Computer-Aided Design of Ion Receptors." Department of Chemistry, University of North Texas, Denton, Texas, April 2003.

- BP Hay. "Computer-Aided Design of Ion Receptors." Department of Chemistry, Texas Tech University, Lubbock, Texas, April 2003.

- BP Hay. "Computer-Aided Design of Ion Receptors." Department of Chemistry, University of Texas, Austin, Texas, April 2003.

- BP Hay. "Computer-Aided Design of Metal Ion Hosts." Science Lecture, Biological and Environmental Research Advisory Council, Washington, D.C., April 2003.

- J Uddin, TK Firman, and BP Hay. "Computer-Aided Design of Complementary and Preorganized Chelate Ring Architectures for Ether and Amine Donor Atoms." Inorganic Chemistry Division, $226^{\text {th }}$ American Chemical Society National Meeting, New York City, New York, September 2003.

- TK Firman and BP Hay. "Computer-Aided Design of Metal Ion Receptors." Radionuclide Decontamination Science and Technology Workshop, Los Alamos Center for Homeland Security, Los Alamos, New Mexico, September 2003.

- BP Hay. "Toward the Computer-Aided Design of Metal Ion Hosts." Chemistry Department Seminar, University of Idaho, Moscow, Idaho, October 2003.

- BP Hay. "Computer-Aided Host Design.” Prof. KN Raymond Group Seminar, University of California - Berkeley, Berkeley, California, January 2004.

- BP Hay. "Computer-Aided Design of Ion Receptors." Chemistry Department Seminar, Washington State University - Tri-Cities, Richland, Washington, March 2004.

- EJ Werner, MK Thompson, BP Hay, M Botta, S Aime, and KN Raymond. "The First Hydroxypyridinone-based Gd(III) Complex with Three Coordinated Waters as a HighRelaxivity MRI Contrast Agent Precursor." Inorganic Chemistry Division Poster Session, $227^{\text {th }}$ American Chemical Society National Meeting, Anaheim, California 2004.

- AV Davis, TK Firman, BP Hay, and KN Raymond. "Isomerization of tris-Catecholate Complexes: The Twisted Sisters of Ti(IV), Ga(III), and Ge(IV) Octahedral Coordination." $36^{\text {th }}$ International Conference on Coordination Chemistry, Merida, Mexico, July 2004.

- BW Parks, RD Gilbertson, JE Hutchison, BM Rapko, BP Hay, and SI Sinkov. "Role of Ligand Preorganization in f-Block Metal Binding as Demonstrated by Bicyclic Diamides." Inorganic Chemistry Division Poster Session, 228 ${ }^{\text {th }}$ American Chemical Society, Philadelphia, Pennsylvania, August 2004.

- BP Hay. "Computer-Aided Design of Ion Receptors." Chemistry Department Seminar, University of Oregon, Eugene, Oregon, November 2004.

- BP Hay. "Computer-Aided Design of Metal Ion Sequestering Agents." Environmental Management Science Program, High Level Waste Workshop, Savannah River National Laboratory, Aiken, South Carolina, January 2005.

- BP Hay and AA Oliferenko. "De Novo Structure-Based Design of Ion Receptors." Division of Computers in Chemistry, Poster Session, 229 ${ }^{\text {th }}$ National American Chemical Society Meeting, San Diego, California, March 2005.

- GJ Lumetta, BP Hay, BM Rapko, JE Hutchison. "Bicyclic Diamides: A Story of Ligand Design." Abstract submitted to the $24^{\text {th }}$ Rare Earth Research Conference to be held in Keystone, Colorado, June 2005.

- BP Hay, VS Bryantsev, and AA Oliferenko. "Molecular Mechanics as a Rapid Screening Tool for De Novo Structure-Based Design of Ion Receptors." Abstract submitted to PacifiChem 2005 to be held in Honolulu, Hawaii, December 2005.

- AA Oliferenko and BP Hay. "Rational Design of Preorganized Polyether Macrocyclic Receptors for Cation Binding. A Fully Integrated Computational Methodology." Abstract submitted to PacifiChem 2005 to be held in Honolulu, Hawaii, December 2005. 
- AA Oliferenko and BP Hay. "Chemical Bonding in Ether - Metal Cation Complexes. A Molecular Orbital and 'Atoms-in-Molecules' Computational Study Abstract submitted to PacifiChem 2005 to be held in Honolulu, Hawaii, December 2005.

\section{Presentations (2000 to 2002):}

- BP Hay. "Building a Better Mousetrap: Ligand Design with Molecular Mechanics." American Chemical Society, Pacifichem 2000 Meeting in Honolulu, Hawaii, December 2000.

- BP Hay, DA Dixon, and BM Rapko. "Computational Design of Metal Ion Sequestering Agents (EMSP 54679)." Tanks Focus Area (TFA) FY 2001 Midyear Review, Salt Lake City, Utah, March 2001.

- RD Gilbertson, BM Rapko, BP Hay, JE Hutchison, and TJR Weakly. "Synthesis of a Conformationally Constrained Malonamide and Its Coordination Chemistry with Uranyl Nitrate." $221^{\text {st }}$ American Chemical Society National Meeting, San Diego, California, April, 2001.

- GJ Lumetta, BK McNamarra, BM Rapko, RD Rogers, GA Broker, and JE Hutchison. "Extraction of U(VI) with Malonamides: What's Really Going On?" $221^{\text {st }}$ American Chemical Society National Meeting, San Diego, California, April, 2001.

- BP Hay. "HostBuilder: A Combinatorial Structure Generator for Host Discovery", Separations Group Seminar, Oak Ridge National Laboratory, Oak Ridge, Tennessee, June 2001.

- BP Hay, DA Dixon, BM Rapko. "Computational Design of Metal Ion Sequestering Agents." EMSP Symposium, 222 ${ }^{\text {nd }}$ American Chemical Society National Meeting, Chicago, Illinois, August 2001.

- TR Klinckman, DA Dixon, and BP Hay. "An MM3 Force Field for Metal Complexes with Amines, Carboxylates, and Aminocarboxylates." Inorganic Poster Session, 222 ${ }^{\text {nd }}$ American Chemical Society National Meeting, Chicago, Illinois, August 2001.

- BP Hay. "Toward the Computer-Aided Design of Metal Ion Hosts." Departmental Seminar, Georgia Institute of Technology, Atlanta, Georgia, October 2001.

- BP Hay. "Toward the Computer-Aided Design of Metal Ion Hosts." Departmental Seminar, University of Memphis, Memphis, Tennessee, October 2001.

- BP Hay. "HostBuilder: A Combinatorial Molecular Structure Generator and Its Application to the Design of Metal Sequestering Agents." Prof. KN Raymond Group Seminar, University of California-Berkeley, Berkeley, California, December 2001. 